\title{
Strong asymmetry of hemispheric climates during MIS-13 inferred from correlating China loess and Antarctica ice records
}

\author{
Z. T. Guo ${ }^{1}$, A. Berger ${ }^{2}$, Q. Z. Yin ${ }^{2}$, and L. Qin ${ }^{1,3}$ \\ ${ }^{1}$ Key Laboratory of Cenozoic Geology and Environment, Institute of Geology and Geophysics, Chinese Academy of \\ Sciences, P.O. Box 9825, Beijing 100029, China \\ ${ }^{2}$ Institut d'Astronomie et de Géophysique G. Lemaître, Université Catholique de Louvain, Chemin du Cyclotron 2, 1348 \\ Louvain-la-Neuve, Belgium \\ ${ }^{3}$ Graduate School of the Chinese Academy of Sciences, Beijing 100039, China
}

Received: 27 August 2008 - Published in Clim. Past Discuss.: 1 October 2008

Revised: 2 February 2009 - Accepted: 2 February 2009 - Published: 18 February 2009

\begin{abstract}
We correlate the China loess and Antarctica ice records to address the inter-hemispheric climate link over the past $800 \mathrm{ka}$. The results show a broad coupling between Asian and Antarctic climates at the glacial-interglacial scale. However, a number of decoupled aspects are revealed, among which marine isotope stage (MIS) 13 exhibits a strong anomaly compared with the other interglacials. It is characterized by unusually positive benthic oxygen $\left(\delta^{18} \mathrm{O}\right)$ and carbon isotope $\left(\delta^{13} \mathrm{C}\right)$ values in the world oceans, cooler Antarctic temperature, lower summer sea surface temperature in the South Atlantic, lower $\mathrm{CO}_{2}$ and $\mathrm{CH}_{4}$ concentrations, but by extremely strong Asian, Indian and African summer monsoons, weakest Asian winter monsoon, and lowest Asian dust and iron fluxes. Pervasive warm conditions were also evidenced by the records from northern high-latitude regions. These consistently indicate a warmer Northern Hemisphere and a cooler Southern Hemisphere, and hence a strong asymmetry of hemispheric climates during MIS-13. Similar anomalies of lesser extents also occurred during MIS-11 and MIS-5e. Thus, MIS-13 provides a case that the Northern Hemisphere experienced a substantial warming under relatively low concentrations of greenhouse gases. It suggests that the global climate system possesses a natural variability that is not predictable from the simple response of northern summer insolation and atmospheric $\mathrm{CO}_{2}$ changes. During MIS-13, both hemispheres responded in different ways leading to anomalous continental, marine and atmospheric conditions at the global scale. The correlations also suggest that the marine $\delta^{18} \mathrm{O}$ record is not always a reliable indicator of the northern ice-volume changes, and that the asymmetry of hemispheric climates is one of the prominent factors control-
\end{abstract}

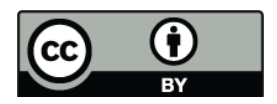

Correspondence to: Z. T. Guo

(ztguo@mail.iggcas.ac.cn) ling the strength of Asian, Indian and African monsoon circulations, most likely through modulating the position of the inter-tropical convergence zone (ITCZ) and land-sea thermal contrasts.

\section{Introduction}

Inter-hemispheric glacial-interglacial covariance is a basic feature of the Pleistocene climate system (Ruddiman, 2003; Schmittner et al., 2003). Climate linkages between the two hemispheres have been examined for the late Quaternary based on ice (Hinnov et al., 2002; Barbante et al., 2006), marine (Pahnke and Zahn, 2005) and some terrestrial records (Lowell et al., 1995). However, much remains to be known about the extent and stability of hemispheric coupling of long-term continental climate changes. Continuous terrestrial records from different geographic locations are of particular value.

The monsoons and inland deserts in Asia are among the key components of the Northern Hemisphere climate system. Their history has been traced back to $\sim 22$ million years (Ma) ago (Guo et al., 2002) and is well recorded by the loess deposits in China (Ding et al., 1995; Porter and An, 1995; Guo et al., 2000, 2002). Asian monsoon may be the strongest among the global monsoon circulations (Wang, 2006) and would have prominent impacts on the atmospheric $\mathrm{CH}_{4}$ concentration through modulating the extent of wetlands (Ruddiman, 2003; Loulergue et al., 2008). Deserts in the Asian inlands are an important source of global eolian dust (Kohfeld and Harrison, 2001), which affects the radiation balance of the atmosphere by absorbing or reflecting incoming solar radiation (Cox et al., 2008), and influences the ocean

Published by Copernicus Publications on behalf of the European Geosciences Union. 

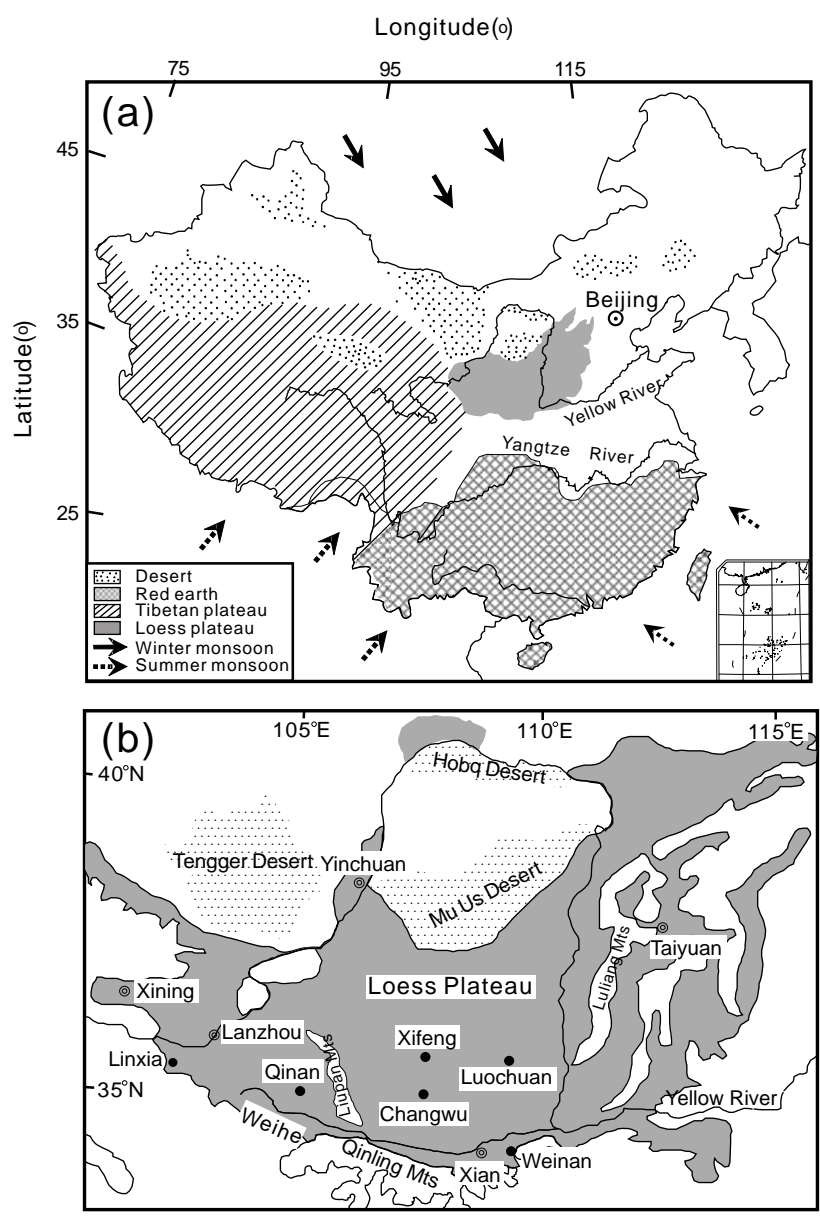

Fig. 1. Maps showing the modern environmental pattern and Loess Plateau in China. (a) Modern environmental pattern and the prevailing atmospheric circulation. Dotted arrows indicate the southwest and southeast Asian summer monsoons and solid arrows indicate the Asian winter monsoon. (b) Loess Plateau in China and the studied sites.

$\mathrm{CO}_{2}$ uptake capacity by modulating the amount of micronutrients (particularly iron) to the ocean (Ridgwell, 2003).

The emitted dust from the Asian inlands was transported by the Asian winter monsoon and deposited in the Loess Plateau in northern China (Fig. 1) where annual rainfall is mainly brought by the Asian summer monsoon (Ding et al., 1995; Porter and An, 1995; Guo et al., 2004). These processes led to the formation of loess-soil alternations with soils corresponding to strengthened summer monsoons and loess to strengthened winter monsoons. Because the summer and winter monsoon circulations originate from northern low- and high-latitudes, respectively, China loess bears climate information of large regional, and to some extent, hemispheric significance.

In the Southern Hemisphere, Antarctic ice records have recently been extended to $\sim 800$ thousand years (ka) ago. The $\delta D$ record provides a history of Antarctic temperature changes (Jouzel et al., 2007). Analyses of the air bubbles yield a high-resolution history of the atmospheric concentrations of greenhouse gases (Petit et al., 1999; Siegenthaler et al., 2005; Loulergue et al., 2008; Luthi et al., 2008). The eolian dust in the ice bears valuable information on atmospheric circulation and climate conditions of the dust source regions in the Southern Hemisphere (Revel-Rilland et al., 2006; Lambert et al., 2008; Marino et al., 2008). Correlating China loess and Antarctica ice records provides an ideal opportunity to evaluate the hemispheric climate link over the past $800 \mathrm{ka}$, the main aim of this study.

\section{Materials and methods}

We use the Quaternary loess sections at Xifeng and Changwu in northern China (Fig. 1) to generate proxies of Asian climates for the last $800 \mathrm{ka}$. Major interglacial soils and glacial loess units are labeled S0, L1, S1, L2, S2, .., S7 and L8 from the top to the bottom with the S5 soil unit subdivided into S5-1, S5-2 and S5-3 (Fig. 2a). Their correlation with the marine $\delta^{18} \mathrm{O}$ stratigraphy has been commonly accepted (Hovan et al., 1989; Kukla et al., 1990; Ding et al., 1995; Guo et al., 2000). Climate proxies were obtained from samples at $10 \mathrm{~cm}$ intervals (723 from Xifeng and 715 from Changwu), representing an average temporal resolution of $\sim 800$ years for loess and $\sim 2000$ years for soils.

Magnetic susceptibility is widely used as an indicator for soil/loess boundaries (Hovan et al., 1989; Kukla et al., 1990; Ding et al., 1995; Guo et al., 2000). Time controls for the loess timescales are determined through correlating magnetic susceptibility with the marine $\delta^{18} \mathrm{O}$ record (Lisiecki and Raymo, 2005) (Fig. 2a) and interpolated using a magnetic susceptibility model (Kukla et al., 1990). Although different timescales are available for the Quaternary loess of China (Kukla et al., 1990; Ding et al., 1995; Heslop et al., 2000), there is no major difference between them for the last $800 \mathrm{ka}$.

Dust flux (Fig. 2b) in loess is mainly determined by the aridity of the source regions in the Asian interior (Hovan et al., 1989; Porter and An, 1995; Guo et al., 2004). It is calculated by assuming a mean dust density of $2.5 \mathrm{~g} \mathrm{~cm}^{-3}$. The $\mathrm{Fe}_{2} \mathrm{O}_{3}$ flux in the China loess, which provides a proportionally quantitative constraint on the eolian iron input from Asia to the ocean, is calculated from the $\mathrm{Fe}_{2} \mathrm{O}_{3}$ content (Fet) multiplied by sedimentation rate and the mean dust density of $2.5 \mathrm{~g} \mathrm{~cm}^{-3}$.

Loess grain-size, especially the contents of the coarse fractions (Fig. 2e), primarily reflects the strength of the Asian winter monsoon (Porter and An, 1995; Ding et al., 1995; Guo et al., 2004), as stronger winds transport coarser dust particles. Grain-size of the Xifeng samples was measured using a Malvern Mastersizer-2000 laser analyzer with an analytical precision of about $1 \%$. Samples were pre-treated with hydrogen peroxide to remove organic matter, then with 


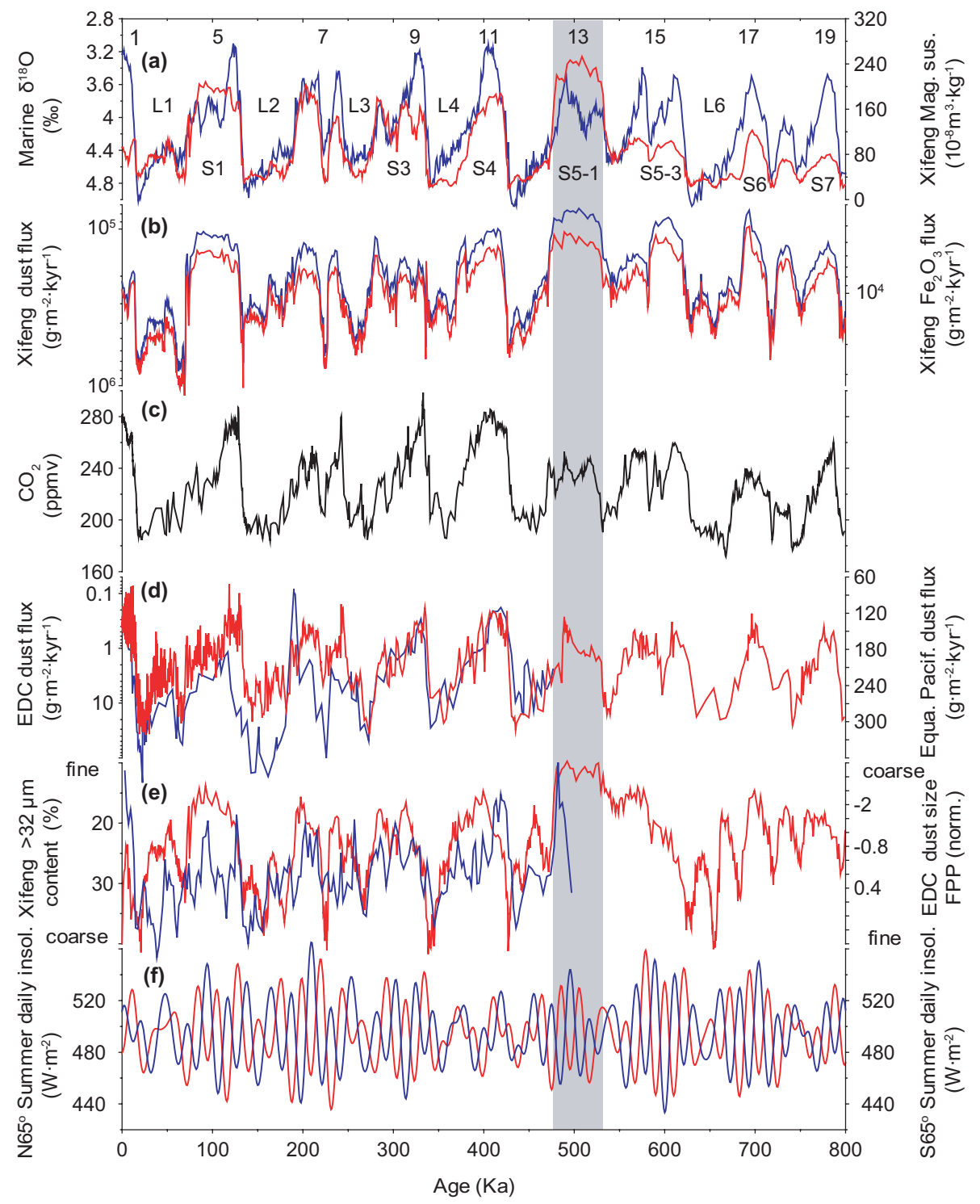

Fig. 2. Correlation of the China loess proxies of Asian dust intensity and winter monsoon with relevant ice and marine records. (a) Marine $\delta^{18} \mathrm{O}$ record (Lisiecki and Raymo, 2005) (blue) with the oxygen isotope stages (MIS) labelled at the top part, and loess magnetic susceptibility at Xifeng (red) with the major soil and loess units labelled; (b) Dust ( blue) and $\mathrm{Fe}_{2} \mathrm{O}_{3}$ flux (red) at Xifeng plotted on log scales; (c) Antarctic (Vostok and EDC) $\mathrm{CO}_{2}$ records (Luthi et al., 2008; Petit et al., 1999; Siegenthaler et al., 2005); (d) EDC (Lambert et al., 2008) (red, log scale) and equatorial Pacific (Winckler et al., 2008) (blue) dust fluxes; (e) Loess grain-size changes shown by the content of the $>32 \mu \mathrm{m}$ fraction at Xifeng (red) and EDC dust size normalized (Lambert et al., 2008) (blue). (f) Summer daily insolation (Berger, 1978) at 65 ${ }^{\circ} \mathrm{N}$ (red) and at $65^{\circ} \mathrm{S}$ (blue). Marine data are plotted versus their own timescales. Antarctic data are plotted versus EDC3 chronology (Parrenin et al., 2007).

hydrochloric acid to remove carbonates, and with sodium hexametaphosphate for dispersion.

Chemical weathering indexes (Fig. 3a) of the China loess are widely used to document the effects of the summer monsoon because soil formation and chemical weathering in the Loess Plateau primarily depend on the monsoon-related summer moisture and temperature (Guo et al., 1998, 2000; Rousseau and Kukla, 2000; Vidic et al., 2000). Its valid- ity has been confirmed by biological (Rousseau and Kukla, 2000; Rousseau et al., 2000), pedological (Guo et al., 1998, 2000) and rock magnetic studies (Vidic et al., 2000). The ratio between free $\mathrm{Fe}_{2} \mathrm{O}_{3}$ (Fed), mainly of pedological origin (Singer et al., 1992; Vidic et al., 2000) and total $\mathrm{Fe}_{2} \mathrm{O}_{3}$ (Fet) is a measurement of the quantity of iron liberated from iron-bearing silicate minerals by chemical weathering relative to the total iron available. This index is widely used 


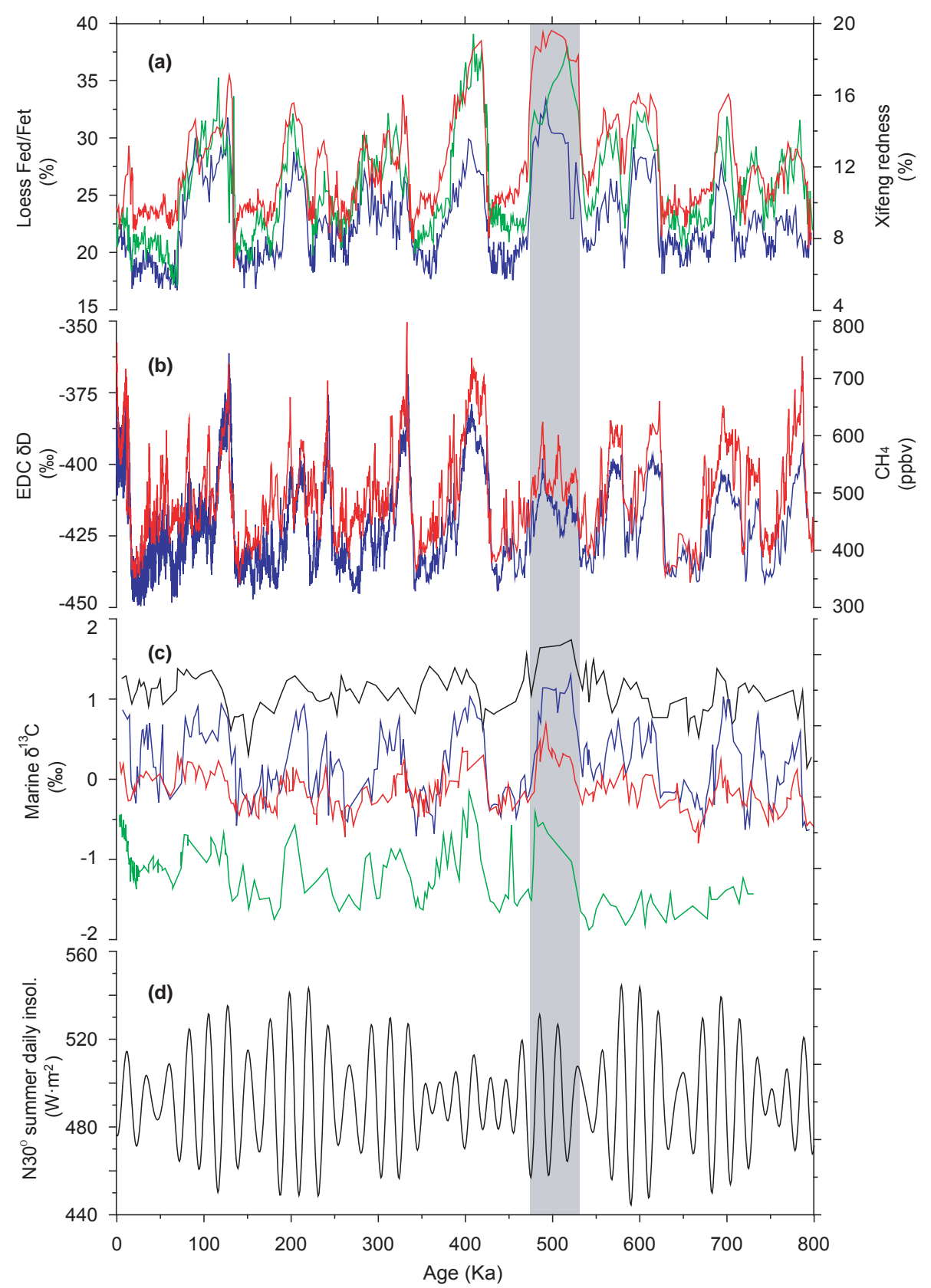

Fig. 3. Correlation of the China loess proxies of Asian summer monsoon with relevant ice and marine records. (a) Chemical weathering index (Guo et al., 2000) (Fed/Fet) at Xifeng (blue), Changwu (green) and the redness at Xifeng (red); (b) EDC $\delta D$ (blue) (Jouzel et al., 2007) and $\mathrm{CH}_{4}$ record (red) (Loulergue et al., 2008); (c) Benthic $\delta^{13} \mathrm{C}$ records from the North Atlantic site 552 (black) (Raymo et al., 1997), tropical Atlantic site 664 (blue) (Raymo et al., 1997), North Pacific site 849 (red) (Raymo et al., 1997) and Southern Ocean site RC 13-229 (green) (Oppo et al., 1990) versus their own timescales. (d) Summer daily insolation (Berger, 1978) at $30^{\circ} \mathrm{N}$.

by pedologists (Duchaufour, 1983) to assess the chemical weathering of soils and has also been successfully used for documenting the history of chemical weathering of the China loess (Guo et al., 1998, 2000). Magnetic susceptibility and $\mathrm{Fed} / \mathrm{Fet}$ data are from Guo et al. (2000).

The degree of reddening of the soils in loess is indicative of pedogenic intensity and largely reflects soil temperature
(Guo et al., 1998, 2000; Yang and Ding, 2003). Redness is measured on samples from Xifeng using a Minolta-CM2002 spectrophotometer with an analytical precision of $\sim 10 \%$ and is expressed as the ratio of red versus total reflectance. 


\section{Results and discussions}

3.1 Broad coupling and decoupled aspects of hemispheric climates

Similar to the Antarctic dust flux (Lambert et al., 2008), dust flux in Asia (Fig. 2b), as is determined by the aridity in the Asian inlands, matches overall the glacial-interglacial cycles with higher values for glacial times. However, the relative glacial-interglacial variability is smaller and the average flux is much higher in Asia than for Antarctica (Fig. 2d). Southern South America may be the dominant dust supplier to Antarctica during cold conditions while Australia also contributed during warm times (Revel-Rolland et al., 2006; Lambert et al., 2008; Marino et al., 2008). Similar glacialinterglacial cycles of dust flux were also observed for the equatorial Pacific (Fig. 2d) (Winckler et al., 2008). These indicate a global-scale link of dust generation, likely attributable to the glacial-interglacial modulation on the global hydrological cycle.

Particle size of loess and eolian dust in marine sediments primarily reflects the wind strength (Hovan et al., 1989; Ding et al., 1995; Porter and An, 1995; Guo et al., 2004). Dust size in China loess exhibits variations similar to those of the dust flux, with coarser dust during glacial times (Fig. 2e). Although the two proxies have different implications, their coupled changes at various scales have been firmly demonstrated and attributed to the Siberian high-pressure cell that influences both Asian aridity and winter monsoon intensity (Ding et al., 1995; Guo et al., 2004). Dust size in Antarctica may be influenced by several factors (Lambert et al., 2008), but the overall negative correlation with Asian dust size (Fig. 2e) suggests some kind of link of the circulations between the two hemispheres.

The consistent changes in dust fluxes in Asia, Antarctica and the equatorial Pacific (Fig. 2) suggest a global-scale increase in the atmospheric dust load and in the input of eolian micronutrients to the ocean during glacial times. This is also shown by the iron flux (Fig. 2b) in the China loess. Both dust and iron fluxes (Fig. 2b) co-varied inversely with the atmospheric $\mathrm{CO}_{2}$ level (Fig. 2c). These do not imply a strong causal link as the glacial-interglacial $\mathrm{CO}_{2}$ changes may relate to a number of other factors, such as the Southern Ocean (Petit et al., 1999; Luthi et al., 2008). Nevertheless, the covariance likely supports the idea about a potential dust- $\mathrm{CO}_{2}$ relationship (Ridgwell, 2003; Winckler et al., 2008), with the relative contribution yet to be determined.

The environmental effect of the Asian summer monsoon in northern China, as reflected by chemical weathering of loess (Fig. 3a), also exhibits changes broadly consistent with the glacial-interglacial cycles. Strong summer monsoons match high peaks of $\mathrm{CH}_{4}$ concentration. This supports the link between the monsoon climate and atmospheric $\mathrm{CH}_{4}$ concentration (Ruddiman, 2003; Loulergue et al., 2008) although other wetlands also play an important role (Loulergue et al., 2008).
Chemical weathering of silicate materials (Gaillardet et al., 1999) may affect the atmospheric $\mathrm{CO}_{2}$ concentration by consuming $\mathrm{CO}_{2}$. However, strong chemical weathering of loess is correlative with high $\mathrm{CO}_{2}$ level (Figs. 2c and 3a), suggesting that this process may be too slow to affect the glacial-interglacial $\mathrm{CO}_{2}$ changes.

The correlations therefore show broadly coupled changes of climates between the Asian and Antarctic continents at the glacial-interglacial scale over the past 800 ka. However, some decoupled features are also obvious.

1. The Antarctic temperature, as reflected by the EDC $\delta D$ record (Fig. $3 \mathrm{~b}$ ), shows a prominent change at $\sim 430 \mathrm{ka}$ (the Mid-Brunhes Event, MBE), characterized by large increases in the interglacial temperature since then, but slightly decreased glacial temperature (Jouzel et al., 2007). The average increase in grain-size (winter monsoon) and dust flux (inland aridity) in Asia during glacial times after $430 \mathrm{ka}$ is roughly consistent with this transition. However, the transition is not clear in the interglacial records of the Asian summer monsoon (Fig. 3a), winter monsoon (Fig. 2e) and inland aridity (Fig. 2b).

2. Although the MIS-13 temperature in Antarctica was lower than for most of the other interglacials of the past $800 \mathrm{ka}$, the strongest summer monsoon, weakest winter monsoon and lowest inland aridity in Asia are recorded in the China loess for this time, and to a lesser extent, for MIS-11 and 5e (Fig. 3a).

3. The largely weakened Asian summer monsoon during glacial times (Fig. 3a) matches the low glacial temperature in Antarctica (Fig. 3b). However, a number of intervals with relatively weak winter monsoons and low inland aridity within some glacial periods are documented in the China loess, such as MIS-16, MIS-14, MIS-12 and MIS-3, but with no clear expression in the Antarctic $\delta D$ record (Fig. $3 \mathrm{~b}$ ). These suggest a greater similarity of the summer monsoon changes to the Antarctic climate during glacial times than for the winter monsoon and inland aridity in Asia.

4. Despite the general coherencies between high/low Asian dust intensity and low/high $\mathrm{CO}_{2}$ levels, between strong/weak Asian summer monsoon and high/low $\mathrm{CH}_{4}$ levels as discussed above, the fluctuation patterns for both the $\mathrm{CO}_{2}$ and $\mathrm{CH}_{4}$ concentrations are, overall, in better agreement with the Antarctic temperature changes (Siegenthaler et al., 2005; Loulergue et al., 2008) than with the Asian climates in the Northern Hemisphere. 
3.2 Anomalous continental, marine and atmospheric conditions during MIS-13

Among these decoupled aspects, a particularly strong anomaly is observed for MIS-13 when compared with other interglacials of the past $800 \mathrm{ka}$. The EDC $\delta D$ record indicates a much cooler interglacial in Antarctica (Fig. 3b) with a temperature $\sim 4^{\circ} \mathrm{C}$ lower than for the Holocene (Jouzel et al., 2007). The marine $\delta^{18} \mathrm{O}$ record (Lisiecki and Raymo, 2005) shows the most positive values, usually interpreted as an indication of larger global ice volume (Fig. 2a).

However, the China loess recorded the lowest inland aridity (Fig. 2b), an extremely weak winter monsoon (Fig. 2e) and an extremely strong summer monsoon (Fig. 3a). MIS13 corresponds to the strongest soil (S5-1) among all Quaternary soils in the China loess (Fig. 2a). Over the Loess Plateau, we estimate that the mean annual temperature increased by at least $4-6^{\circ} \mathrm{C}$ and the annual rainfall by 200 $300 \mathrm{~mm}$ compared to today (Guo et al., 1998). An unusually strong Asian summer monsoon is expressed in southern China by the development of a widely spread vermiculated soil complex (Yin and Guo, 2006, 2008) indicative of extremely warm and humid conditions. Warmer and more humid Asian inlands are also reflected by reduced mass accumulation rates of Asian dust in the North Pacific (Hovan et al., 1989).

The extreme conditions of MIS-13 were not limited to the Asian monsoon zone and inland deserts. MIS-13 was also recognized as the warmest interglacial of the past $800 \mathrm{ka}$ in the elevated Tibetan Plateau from the presence of forest conditions (Chen et al., 1999). Particularly warm conditions were also identified in the non-monsoonal Baikal region (Prokopenko et al., 2002), in eastern Europe (Marković et al., 2009), northern Europe (Vandenberghe, 2000; Zagwijn, 1996) and Greenland (De Vernal and Hillaire-Marcel, 2008), all in high-latitude continents of the Northern Hemisphere. Unusually strong African (Rossignol-Strick et al., 1998) and Indian (Bassinot et al., 1994) monsoons at this time were also recorded respectively by a thick Mediterranean sapropel resulting from high flooding of the Nile river, and by an extremely low surface salinity in the equatorial Indian Ocean, suggesting commonly strengthened monsoon circulations in the Northern Hemisphere.

In the global ocean, $\delta^{13} \mathrm{C}$ records of the past $800 \mathrm{ka}$ from the North Atlantic (Raymo et al., 1997; McManus et al., 1999), tropical Atlantic (Raymo et al., 1997), and the Pacific (Raymo et al., 1997) show a global-scale positive anomaly during MIS-13 (Fig. 3c). The Atlantic $\delta^{13} \mathrm{C}$ gradient (Raymo et al., 1997) suggests a strong input of North Atlantic Deep Water (NADW) to the tropical Atlantic. High $\delta^{13} \mathrm{C}$ values were also present in the Southern Ocean (Oppo et al., 1990) (Fig. 3c). These indicate that the event had links with the ocean circulation and carbon cycle.

ODP 908 site from the North Atlantic shows a total lack of ice-rafted debris (McManus et al., 1999) during a long inter- val within MIS-13, the only such case in the 500-ka record. Although the amount of ice-rafted debris is site-dependent, most of the records from circum-Arctic oceans indicate a reduced intensity of ice rafting, typical of a warm interglacial.

In contrast, summer sea surface temperature (SSST) in the sub-Antarctic Atlantic during MIS-13 was the lowest among interglacials of the past $550 \mathrm{ka}$ (Becquey and Gersonde, 2003). Lower sea surface temperature was also observed in the Southeast Atlantic (McClymont et al., 2005) and Southwest Pacific (King and Howard, 2000).

During MIS-13, anomalous conditions were also obvious in the low-latitude Pacific where the East Asian summer monsoon originates. Surface water $\delta^{18} \mathrm{O}$ showed an extremely low surface salinity (De Garidel-Thoron et al., 2005) in the west Pacific warm pool. SST had a great variability, but was lower than for the other interglacials during most of the MIS-13 (De Garidel-Thoron et al., 2005). The percentages of warm surface and subsurface planktonic foraminifers in South China Sea were also significant lower than for the other interglacials (Li et al., 2008).

Atmospheric conditions were also anomalous during MIS13. Although dust size (Fig. 2e) in Antarctica may only reflect regional subsidence (Lambert et al., 2008), the coarsest EDC dust size during MIS-13, coinciding with the monsoon anomalies in the Northern Hemisphere, appears to suggest a prominent change in the circulation of both hemispheres. A particularly prominent anomaly is the association of pervasive warm conditions in the Northern Hemisphere with the rather low atmospheric $\mathrm{CO}_{2}$ concentration during MIS-13, which represents the second lowest interglacial value in the past 800 ka after MIS-17 (Fig. 2c).

Monsoonal wetlands in the Northern Hemisphere are among the dominant sources (Ruddiman, 2003; Loulergue et al., 2008) of atmospheric $\mathrm{CH}_{4}$. The unusually strong Asian, African and Indian monsoons, as well as the warm-humid conditions over the Northern Hemisphere continents during MIS-13 should have led to increased $\mathrm{CH}_{4}$ emissions. However, the atmospheric $\mathrm{CH}_{4}$ concentration at this time was the lowest among interglacials of the past $800 \mathrm{ka}$ (Fig. 3b).

Our correlation thus indicates for MIS-13 (1) prominent anomalies in the continental, marine and atmospheric environments; (2) a strong asymmetry of hemispheric climates marked by average cooler conditions in the Southern Hemisphere and generally warmer conditions in the Northern Hemisphere; and (3) anomalous links between the northern hemispheric climates and the atmospheric concentrations of $\mathrm{CO}_{2}$ and $\mathrm{CH}_{4}$ in comparison with the other interglacials.

\subsection{Strong asymmetry of hemispheric climates during MIS-13}

The strong imprints of the MIS-13 anomaly in continental, marine and atmospheric environments require a global-scale perspective. 
Summer insolation changes at low northern latitudes have deep impacts on the Asian, Indian and African monsoons, with insolation maxima resulting in strengthened summer monsoons (Bassinot et al., 1994; Kutzbach and Liu, 1997; Ruddiman, 2003). Although insolation maxima also occurred within MIS-13 at substages MIS-13.3, 13.13 and 13.11 (Berger, 1978), the values are not higher than for other interglacials (Fig. 3d), and consequently, cannot alone explain the extremely strengthened monsoons in the Northern Hemisphere.

Because the Asian winter monsoon has a high-latitude origin, its strength is largely dependent on northern highlatitude conditions. Climate models (Ruddiman and Kutzbach, 1989; Wu and Wang, 2002) and geological records (Ding et al., 1995; Porter and An, 1995; Guo et al., 2004) consistently indicate a strong impact of northern ice-sheets and sea ice on inland aridity and winter monsoon strength in Asia through modulating the winter intensity of the Siberian High. Long-term changes in eolian grain-size and dust flux of the China loess were closely coupled with ice-rafting intensity in the circum-Arctic ocean and development of Northern Hemisphere ice-sheets over the past $6 \mathrm{Ma}$ (Guo et al., 2004). The general correlation of the China loess stratigraphy with the marine $\delta^{18} \mathrm{O}$ record (Fig. 2a) validates this link at the glacial-interglacial scale (Hovan et al., 1989; Kukla et al., 1990; Ding et al., 1995). Ice-rafting events in the North Atlantic led to pulses of strong Asian winter monsoon at millennial scales (Porter and An, 1995). These consistently indicate a close dynamical link of the Asian winter monsoon and inland aridity with the northern ice-sheet/sea ice conditions. Consequently, the very low inland aridity and weak winter monsoon during MIS-13 in Asia indicate that ice forcing was largely weakened.

Marine $\delta^{18} \mathrm{O}$ records of benthic foraminifera in the past $800 \mathrm{ka}$ are primarily interpreted as an indication of global ice volume (Lisiecki and Raymo, 2005), but do not discriminate signals between the southern and the northern ice-sheets. The above lines of evidence argue against the interpretation that relatively high interglacial $\delta^{18} \mathrm{O}$ values during MIS-13 were the result of greater ice-sheets in the Northern Hemisphere. Rather, they indicate smaller northern ice-sheets than for other interglacials, consistent with the particularly abundant pollen at this time at ODP site 646 reflecting a substantially reduced Greenland ice sheet (De Vernal and HillaireMarcel, 2008), and with the largely weakened Asian winter monsoon and inland aridity that indicate weakened iceforcing in high-latitude Eurasia.

Thus, the most positive marine $\delta^{18} \mathrm{O}$ values (Lisiecki and Raymo, 2005) during MIS-13 must have resulted from other effects. First, ice-sheets on Antarctica would have been either thicker or more extensive than for other interglacials because of the much lower air temperature (Jouzel et al., 2007) and South Atlantic summer SST (Becquey and Gersonde, 2003). However, this effect may not account for the total anomaly in the marine $\delta^{18} \mathrm{O}$ values because ice extent in Antarctica is constrained by sea level (Bye et al., 2006). With a northern ice volume smaller than for the other interglacials, Antarctic ice-sheet extent could not be much larger although it could be thicker. Alternatively, the more positive marine $\delta^{18} \mathrm{O}$ values during MIS-13 could result from colder deep ocean temperature. In view of the $\sim 4^{\circ} \mathrm{C}$ lower air temperature in Antarctica (Jouzel et al., 2007), the cold anomaly would have chilled the bottom waters sinking around Antarctica and thereby shift the benthic $\delta^{18} \mathrm{O}$ signals towards heavier values.

Hence, whatever the size of the southern ice-sheets during MIS-13, most of the evidence defines an unusual interglacial, characterized by a much warmer Northern Hemisphere, a much cooler Southern Hemisphere, and hence a strong asymmetry of hemispheric climates. The northern ice-sheets were smaller and sea ice at northern high-latitudes was less developed. In contrast, the lower air and summer sea surface temperature near Antarctica would have favoured more extended sea ice. Consequently, we believe that the sea ice conditions at the high-latitudes of the two hemispheres were asymmetrical.

This scenario is consistent with most of the observed features in the continental, marine and atmospheric environments during MIS-13 according to the following mechanisms yielded by geological records and climate models for some other periods.

Warmer conditions in the Northern Hemisphere continents, particularly in the Tibetan Plateau (Chen et al., 1999), enhance land-sea thermal contrasts and reinforce summer monsoon circulations (Ruddiman, 2003; Ruddiman and Kutzbach, 1989). Reduced winter and spring snow cover over Eurasia is also particularly favourable to stronger southwest summer monsoon winds (Goes et al., 2005). These conditions during MIS-13, associated with precession-driven insolation maxima at northern low-latitudes (Berger, 1978) and lower interglacial low-latitude SST (De Garidel-Thoron et al., 2005; Li et al., 2008), can largely explain the unusually strengthened monsoons in the Northern Hemisphere.

A meridional shift of the atmospheric circulation may also have played an important role. Today, the intertropical convergence zone (ITCZ) penetrates into the Northern Hemisphere in summer as far as $24^{\circ} \mathrm{N}$ due to hemispheric asymmetry and reinforces the northern monsoon circulations (Wang, 2006). Climate records and model experiments showed that a further shift can be induced by more extended sea ice over the Southern Ocean, cooler temperature in the Southern Hemisphere (Iriondo, 2000; Markgraf et al., 2000), and reduced dust aerosol in the Northern Hemisphere (Cox et al., 2008). Because MIS-13 is marked by these conditions, this would provide a complementary explanation of the strong summer monsoons in the Northern Hemisphere during MIS-13.

A cooler MIS-13 in the Southern Hemisphere would favour a reduced terrestrial biomass, but a warmer and more humid Northern Hemisphere would have led to globally 
increased terrestrial biomass (Duplessy et al., 1984, 2007). This partly explains the higher marine $\delta^{13} \mathrm{C}$ values and lower atmospheric $\mathrm{CO}_{2}$ level. The lower Antarctica temperature and a cooler Southern Ocean during MIS-13 also favour a lower $\mathrm{CO}_{2}$ concentration (Ruddiman, 2003; Siegenthaler et al., 2005; Luthi et al., 2008).

MIS-13 is also an example of decoupling between the strong northern monsoon circulations and atmospheric $\mathrm{CH}_{4}$ concentration. This anomalous link needs to invoke an offset by strongly reduced $\mathrm{CH}_{4}$ emission from other regions. The wetlands in the Southern Hemisphere would have emitted less $\mathrm{CH}_{4}$ in view of the cooler conditions. The boreal wetlands in the Northern Hemisphere would have been omitting large amounts during warmer summers. Another possibility is $\mathrm{CH}_{4}$ emitted from sources very near the equator but offshore the northern monsoonal continents. The northward movement of the ITCZ caused by the hemispheric asymmetry might have brought unusually cool temperatures to those regions and suppressed $\mathrm{CH}_{4}$ emissions, consistent with lower SST in the low-latitude Pacific (De Garidel-Thoron et al., 2005) and South China Sea (Li et al., 2008).

Smaller northern ice-sheets would have also occurred within stages MIS-11 and MIS-5e, as suggested by the stronger summer monsoon (Fig. 3a), low dust intensity and weak winter monsoon in Asia (Fig. $2 b$ and e). These are consistent with the more abundant pollen during these two periods at ODP site 646 that indicate a reduced Greenland ice-sheet (De Vernal and Hillaire-Marcel, 2008). Marine records also show a positive $\delta^{13} \mathrm{C}$ anomaly (Oppo et al., 1990; Raymo et al., 1997) (Fig. 3c), greater NADW input to the Southern Ocean (Oppo et al., 1990) and a near-absence of ice rafting near the Arctic (McManus et al., 1999). However, they differ from MIS-13 by the more negative marine $\delta^{18} \mathrm{O}$ values (Fig. 2a), warmer Antarctic temperature (Fig. 3b), and higher $\mathrm{CO}_{2}$ and $\mathrm{CH}_{4}$ levels (Figs. $2 \mathrm{c}$ and $3 b$ ). This evidence suggests a lesser asymmetry of hemispheric climates than for MIS-13.

The cause of the enhanced asymmetry of hemispheric climates during MIS-13 remains to be addressed. Greenhouse warming may cause similar asymmetry of sea ice (Manabe et al., 1992; Cavalieri et al., 1997), but cannot account for MIS-13 because of its lower $\mathrm{CO}_{2}$ and $\mathrm{CH}_{4}$ levels.

Insolation is a possible cause. Although the $\mathrm{CO}_{2}$ concentration was $\sim 40$ ppmv lower (Luthi et al., 2008) in MIS-13 than the pre-industrial level (equivalent to a radiative forcing of $\sim-0.82 \mathrm{Wm}^{-2}$ ), high northern latitudes received more energy during their summer when this season occurred at perihelion, i.e. three times in MIS-13 at 529, 506, and $485 \mathrm{ka}$ BP. For example, summer insolation at $65^{\circ} \mathrm{N}$ was $50 \mathrm{Wm}^{-2}$ higher at $506 \mathrm{ka}$ ago (Fig. 2f) when eccentricity was much larger (Berger, 1978). The consequent net increase of energy received by the northern high-latitudes would favour ice melting. On the contrary, summer insolation at $65^{\circ} \mathrm{S}$ was $50 \mathrm{Wm}^{-2}$ lower (Berger, 1978) at $506 \mathrm{ka}$ ago. This, associated with the lower concentrations of greenhouse gases
(Loulergue et al., 2008; Luthi et al., 2008), would favour ice building in the Southern Hemisphere. This also happened at $485 \mathrm{ka} \mathrm{BP}$, but at $529 \mathrm{ka} \mathrm{BP}$ the amplitude of the seasonal anomaly was reduced due to a lower eccentricity. On the other hand, insolation anomalies at MIS-5e were even larger than at $506 \mathrm{ka}$ BP due to a larger eccentricity (Berger, 1978), consistent with the stronger summer monsoon (Fig. 3a), weaker winter monsoon and lower dust intensity in Asia (Fig. 2e and 3a). In addition, MIS-13 and MIS11 coincide with a mid-Pleistocene interval of lower amplitude changes of summer insolation at northern high-latitudes (Berger, 1978) from $\sim 570$ to $340 \mathrm{ka} \mathrm{BP} \mathrm{(Fig.} \mathrm{2f).} \mathrm{The} \mathrm{higher}$ values of the insolation minima would oppose ice building in the Northern Hemisphere.

Insolation is unlikely to be the only cause because similar insolation patterns also occurred for other times when monsoons were not necessarily strong (for example MIS7, $242 \mathrm{ka} \mathrm{BP}$ ). Internal climate processes must have amplified the initial effects of insolation. Stronger NADW formation, as suggested by oceanographic data (Raymo et al., 1997; McManus et al., 1999), should be considered as it may modulate meridional heat transport (Broecker, 1998), and favors climate asymmetry between the two hemispheres. Because NADW has initially heavier ${ }^{13} \mathrm{C}$ values and migrates to other marine basins (Duplessy et al., 1984, 2007; Raymo et al., 1997), it also partly explains the $\delta^{13} \mathrm{C}$ anomaly in the global ocean. We believe that the greatly reinforced northern summer monsoon circulations would have also helped energy transport to the Northern Hemisphere.

Although hemispheric coupling of glacial-interglacial changes is a basic feature of the Pleistocene climate system (Ruddiman, 2003; Schmittner et al., 2003), our correlation indicates that hemispheric climates have at times evolved with relative independence, leading to an unstable coupling during the Mid-Pleistocene. Clearly, the global climate system possesses a natural variability that is not predictable from simple responses to northern summer insolation and changes of the greenhouse gases. During MIS-13, both hemispheres responded in different ways, leading to anomalous continental, marine and atmospheric conditions. The correlations also suggest that marine $\delta^{18} \mathrm{O}$ records are not always a reliable indicator of ice-volume changes in northern high-latitudes. Its values may be occasionally dominated more by signals from either southern ice-sheets or deep ocean temperature, or a combination of both. Our study also suggests that the asymmetry of hemispheric climates is also a prominent factor controlling the strength of the Asian, Indian and African monsoon circulations, most likely through modulating the position of the inter-tropical convergence zone (ITCZ) and land-sea thermal contrasts.

These phenomena may also have implications for other decoupled aspects between the China loess and Antarctica ice records discussed in Sect. 3.1, and for the evolution of the climate system during other periods of the Quaternary. Because either geological records (Ding et al., 1995; Porter and An, 
1995; Guo et al., 2004) or climate models (Ruddiman and Kutzbach, 1989; Wu and Wang, 2002) indicate a close link between the Asian winter monsoon and ice conditions in the northern high-latitudes, the rather ambiguous expression of the MBE transition in the interglacial Asian climate and the weakened winter monsoon/inland aridity within some glacial intervals might also be linked to a weakened ice forcing at northern high-latitudes. In contrast, the coarsest loess unit L9 (correlative to MIS-22) in China, an indication of particularly strengthened winter monsoon circulation and inland aridity in Asia (Guo et al., 1998), might be linked to substantially increased northern ice-sheets versus smaller ones in the Southern Hemisphere because the globally total ice volume, as indicated by the marine $\delta^{18} \mathrm{O}$ record (Lisiecki and Raymo, 2005), was not greater than for the other glacial periods. Further understanding of these issues would require new terrestrial and marine records, particularly from the polar regions, to independently trace the evolutions of their ice and climate conditions. Ice modelling is also of high importance.

Large-amplitude waxing and waning of ice-sheets are a relatively slow process at geological scales, but extents of sea ice can vary at century and decadal scales and currently show a decreasing trend in the Northern Hemisphere (Cavalieri et al., 1997). This suggests that asymmetric scenarios similar to that of MIS-13 may operate at shorter-terms.

\section{Conclusions}

Our correlation between the China loess, Antarctic ice and marine isotope records showed the following main insights related to the hemispheric climate link over the past $800 \mathrm{ka}$.

The climates in Asia and Antarctica were broadly coupled at glacial-interglacial scale over the past $800 \mathrm{ka}$, consistent with the other Pleistocene climate records from both hemispheres. General coherencies are observed between high/low Asian dust intensity and low/high $\mathrm{CO}_{2}$ levels, between strong/weak Asian summer monsoon and high/low $\mathrm{CH}_{4}$ concentrations following the glacial-interglacial cycles, although these do not necessarily imply an effective causal link between the dust emission and atmospheric $\mathrm{CO}_{2}$ at the glacial-interglacial scale.

The correlation reveals a number of decoupled aspects between the loess and ice records. Among them, a strong anomaly is observed for MIS-13 compared with the other interglacials. Comprehensive examination of the relevant geological records consistently suggests a significantly cooler Southern Hemisphere, but an unusually warmer Northern Hemisphere with reduced northern ice volume, and hence, an enhanced asymmetry of hemispheric climates. During this interglacial, both hemispheres responded in different ways to the northern summer insolation and atmospheric $\mathrm{CO}_{2}$ changes.
MIS-13 is therefore a real case of a substantial northern hemispheric warming under relatively low concentrations of greenhouse gases. Smaller northern ice-sheets would have also occurred during MIS-11 and MIS-5e, with apparently a lesser hemispheric asymmetry than for MIS-13. These also suggest that the coupling of hemispheric climates at the glacial-interglacial scales was significantly unstable in the Mid-Pleistocene and that marine $\delta^{18} \mathrm{O}$ records may not be always reliable indicators of northern ice-volume. These findings may also have implications for the evolution of the climate system during other periods of the Quaternary.

Our study also suggests that the asymmetry of hemispheric climates is a prominent factor controlling the Asian, Indian and African monsoon circulations. The cause of the hemispheric climate difference remains to be further addressed. An initial effect of insolation and amplification by the oceanic and atmospheric circulations are likely factors to be considered.

Acknowledgements. This research was supported by grants from Chinese Academy of Sciences (KZCX2-YW-117), National Natural Science Foundation of China (40730104) and the Ministry of Science and Technology (2007FY110200). Qiuzhen Yin benefits from a postgraduate grant from Université Catholique de Louvain. Thanks are extended to D. Raynaud for valuable suggestions and discussions, to J. Petit and W. Ruddiman for the highly constructive reviews and helps in improving the manuscript.

Edited by: D.-D. Rousseau

\section{References}

Barbante, C., Barnola, J.-M., Becagli, S., et al.: One-to-one coupling of glacial climate variability in Greenland and Antarctica, Nature, 444, 195-198, 2006.

Bassinot, F. C., Labeyrie, L. D., Vincent, E., Quidelleur, X., Shackleton, N. J., and Lancelot, Y.: The astronomical theory of climate and the age of the Brunhes-Matuyama magnetic reversal, Earth Planet. Sc. Lett., 126, 91-108, 1994.

Becquey, S. and Gersonde, R.: A 0.55-Ma paleotemperature record from the Subantarctic zone: Implications for Antarctic Circumpolar Current development, Paleoceanography, 18, 1014, doi:10.1029/2000PA000576, 2003.

Berger, A.: Long-term variations of daily insolation and Quaternary climate changes, J. Atmos. Sci., 35, 2362-2367, 1978.

Broecker, W. S.: Paleocean circulation during the last deglaciation: A bipolar seesaw?, Paleoceanography, 13, 119-121, 1998.

Bye, J., May, J., and Simmonds, I.: Control of the antarctic ice sheet by ocean-ice interaction, Global Planet. Change, 50, 99111, 2006.

Cavalieri, D. J., Gloersen, P., Parkinson, C. L., Comiso, J. C., and Zwally, H. J.: Observed hemispheric asymmetry in global sea ice changes, Science, 278, 1104-1106, 1997.

Chen, F. H., Bloemendal, J., Zhang, P. Z., and Liu, G. X.: An 800 ky proxy record of climate from lake sediments of the Zoige Basin, eastern Tibetan Plateau, Palaeogeogr. Palaeoclimatol. Palaeoecol., 151, 307-320, 1999. 
Cox, P. M., Harris, P. P., Huntingford, C., Betts, R. A., Collins, M., Jones, C. D., Jupp, T. E., Marengo, J. A., and Nobre, C. A.: Increasing risk of Amazonian drought due to decreasing aerosol pollution, Nature, 453, 212-215, 2008.

De Garidel-Thoron, T., Rosenthal, Y., Bassinot, F., and Beaufort, L.: Stable sea surface temperatures in the western pacific warm pool over the past 1.75 million years, Nature, 433, 294-298, 2005.

De Vernal, A. and Hillaire-Marcel, C.: Natural variability of Greenland climate, vegetation, and ice volume during the past million years, Science, 320, 1622-1625, 2008.

Ding, Z. L., Liu, T. S., Rutter, N. W., Yu, Z. W., Guo, Z. T., and Zhu, R. X.: Ice-volume forcing of East Asian winter monsoon variations in the past 800,000 years, Quat. Res., 44, 149-159, 1995.

Duchaufour, P.: Pedologie, Tome 1: Pedogenese et Classification, Masson, Paris-New York-Barcelone-Milan, 1983.

Duplessy, J. C., Shackleton, N. J., Matthews, R. K., Prell, W., Ruddiman, W. F., Caralp, M., and Hendy, C. H.: ${ }^{13} \mathrm{C}$ record of benthic foraminifera in the last interglacial ocean: implications for the carbon cycle and the global deep water circulation, Quat. Res., 21, 225-243, 1984.

Duplessy, J. C., Roche, D. M., and Kageyama, M.: The deep ocean during the last interglacial period, Science, 316, 89-91, 2007.

Gaillardet, J., Dupre, B., Louvat, P., and Allegre, C. J.: Global silicate weathering and $\mathrm{CO}_{2}$ consumption rates deduced from the chemistry of large rivers, Chem. Geol., 159, 3-30, 1999.

Goes, J. I., Thoppil, P. G., Gomes, H. D., and Fasullo, J. T.: Warming of the Eurasian landmass is making the Arabian sea more productive, Science, 308, 545-547, 2005.

Guo, Z. T., Biscaye, P., Wei, L. Y., Chen, X. H., Peng, S. Z., and Liu, T. S.: Summer monsoon variations over the last 1.2 Ma from the weathering of loess-soil sequences in China, Geophys. Res. Lett., 27, 1751-1754, 2000.

Guo, Z. T., Peng, S. Z., Hao, Q. Z., Biscaye, P. E., An, Z. S., and Liu, T. S.: Late Miocene-Pliocene development of Asian aridification as recorded in the Red-Earth Formation in northern China, Global Planet. Change, 41, 135-145, 2004.

Guo, Z. T., Liu, T. S., Fédoroff, N., Wei, L. Y., Ding, Z. L., Wu, N. Q., Lu, H. Y., Jiang, W. Y., and An, Z. S.: Climate extremes in loess of China coupled with the strength of deep-water formation in the North Atlantic, Global Planet. Change, 18, 113-128, 1998.

Guo, Z. T., Ruddiman, W. F., Hao, Q. Z., Wu, H. B., Qiao, Y. S., Zhu, R. X., Peng, S. Z., Wei, J. J., Yuan, B. Y., and Liu, T. S.: Onset of Asian desertification by $22 \mathrm{Myr}$ ago inferred from loess deposits in China, Nature, 416, 159-163, 2002.

Heslop, D., Langereis, C. G., and Dekkers, M. J.: A new astronomical timescale for the loess deposits of Northern China, Earth Planet. Sci. Lett., 184, 125-139, 2000.

Hinnov, L. A., Schulz, M., and Yiou, P.: Interhemispheric spacetime attributes of the Dansgaard-Oeschger oscillations between 100 and 0 ka, Quat. Sci. Rev., 21, 1213-1228, 2002.

Hovan, S. A., Rea, D. K., Pisias, N. G., and Shackleton, N. J.: A direct link between the China loess and marine ${ }^{18} \mathrm{O}$ records: aeolian flux to the north Pacific, Nature, 340, 296-298, 1989.

Iriondo, M.: Patagonian dust in Antarctica, Quat. Int., 68, 83-86, 2000.

Jouzel, J., Masson-Delmotte, V., Cattani, O., Dreyfus, G., Falourd, S., Hoffmann, G., Minster, B., Nouet, J., Barnola, J. M., Chappellaz, J., Fischer, H., Gallet, J. C., Johnsen, S., Leuenberger, M.,
Loulergue, L., Luethi, D., Oerter, H., Parrenin, F., Raisbeck, G., Raynaud, D., Schilt, A., Schwander, J., Selmo, E., Souchez, R., Spahni, R., Stauffer, B., Steffensen, J. P., Stenni, B., Stocker, T. F., Tison, J. L., Werner, M., and Wolff, E. W.: Orbital and millennial Antarctic climate variability over the past 800,000 years, Science, 317, 793-796, 2007.

King, A. L. and Howard, W. R.: Middle Pleistocene sea-surface temperature change in the southwest Pacific Ocean on orbital and suborbital time scales, Geology, 28, 659-662, 2000.

Kohfeld, K. E. and Harrison, S. P.: DIRTMAP: the geological record of dust, Earth Sci. Rev., 54, 81-114, 2001.

Kukla, G., An, Z. S., Melice, J. L., Gavin, J., and Xiao, J. L.: Magnetic susceptibility record of Chinese Loess, T. Roy. Soc. Edin.Earth, 81, 263-288, 1990.

Kutzbach, J. E. and Liu, Z.: Response of the African monsoon to orbital forcing and ocean feedbacks in the middle Holocene, Science, 278, 440-443, 1997.

Lambert, F., Delmonte, B., Petit, J. R., Bigler, M., Kaufmann, P. R., Hutterli, M. A., Stocker, T. F., Ruth, U., Steffensen, J. P., and Maggi, V.: Dust-climate couplings over the past 800,000 years from the EPICA Dome C ice core, Nature, 452, 616-619, 2008.

Li, Q., Wang, P., Zhao, Q., Tian, J., Cheng, X., Jian, Z., Zhong, G., and Chen, M.: Paleoceanography of the mid-pleistocene south china sea, Quat. Sci. Rev., 27, 1217-1233, 2008.

Lisiecki, L. E. and Raymo, M. E.: A Pliocene-Pleistocene stack of 57 globally distributed benthic $\delta^{18} \mathrm{O}$ records, Paleoceanography, 20, PA1003, doi:10.1029/2004PA001071, 2005.

Loulergue, L., Schilt, A., Spahni, R., Masson-Delmotte, V., Blunier, T., Lemieux, B., Barnola, J. M., Raynaud, D., Stocker, T. F., and Chappellaz, J.: Orbital and millennial-scale features of atmospheric $\mathrm{CH}_{4}$ over the past 800,000 years, Nature, 453, 383386, 2008.

Lowell, T. V., Heusser, C. J., Andersen, B. G., Moreno, P. I., Hauser, A., Heusser, L. E., Schluchter, C., Marchant, D. R., and Denton, G. H.: Interhemispheric correlation of Late Pleistocene glacial events, Science, 269, 1541-1549, 1995.

Luthi, D., Le Floch, M., Bereiter, B., Blunier, T., Barnola, J. M., Siegenthaler, U., Raynaud, D., Jouzel, J., Fischer, H., Kawamura, K., and Stocker, T. F.: High-resolution carbon dioxide concentration record 650,000-800,000 years before present, Nature, 453, 379-382, 2008.

Markgraf, V., Baumgartner, T. R., Bradbury, J. P., Diaz, H. F., Dunbar, R. B., Luckman, B. H., Seltzer, G. O., Swetnam, T. W., and Villalba, R.: Paleoclimate reconstruction along the Pole-EquatorPole transect of the Americas (PEP 1), Quat. Sci. Rev., 19, 125140, 2000.

Marković, S. B., Hambach, U., Catto, N., Jovanović, M., Buggle, B., Machalett, B., Zöller, L., Glaser, B., and Frechen, M.: The middle and late Pleistocene loess sequences at Batajnica, Vojvodina, Serbia, Quat. Int., in press, 2009.

Manabe, S., Spelman, M. J., and Stouffer, R. J.: Transient responses of a coupled ocean atmosphere model to gradual changes of atmospheric $\mathrm{CO}_{2}$. 2. Seasonal response, J. Climate, 5, 105-126, 1992.

Marino, F., Castellano, E., Ceccato, D., De Deckker, P., Delmonte, B., Ghermandi, G., Maggi, V., Petit, J., Revel-Rolland, M., and Udisti, R.: Defining the geochemical composition of the epica dome c ice core dust during the last glacialinterglacial cycle, Geochem. Geophys. Geosyst., 9, Q10018, 
doi:10.1029/2008GC002023, 2008.

McClymont, E. L., Rosell-Mele, A., Giraudeau, J., Pierre, C., and Lloyd, J. M.: Alkenone and coccolith records of the midpleistocene in the south-east atlantic: Implications for the u37(k) index and south african climate, Quat. Sci. Rev., 24, 15591572,2005

McManus, J. F., Oppo, D. W., and Cullen, J. L.: A 0.5-millionyear record of millennial-scale climate variability in the North Atlantic, Science, 283, 971-975, 1999.

Oppo, D. W., Fairbanks, R. G., and Gordon, A. L.: Late Pleistocene Southern Ocean $\delta^{13} \mathrm{C}$ variability, Paleoceanography, 5, 43-54, 1990.

Pahnke, K. and Zahn, R.: Southern hemisphere water mass conversion linked with North Atlantic climate variability, Science, 307, 1741-1746, 2005.

Parrenin, F., Barnola, J.-M., Beer, J., Blunier, T., Castellano, E., Chappellaz, J., Dreyfus, G., Fischer, H., Fujita, S., Jouzel, J., Kawamura, K., Lemieux-Dudon, B., Loulergue, L., MassonDelmotte, V., Narcisi, B., Petit, J.-R., Raisbeck, G., Raynaud, D., Ruth, U., Schwander, J., Severi, M., Spahni, R., Steffensen, J. P., Svensson, A., Udisti, R., Waelbroeck, C., and Wolff, E.: The EDC3 chronology for the EPICA Dome C ice core, Clim. Past, 3, 485-497, 2007, http://www.clim-past.net/3/485/2007/.

Petit, J. R., Jouzel, J., Raynaud, D., Barkov, N. I., Barnola, J.-M., Basile, I., Bender, M., Chappellaz, J., Davisk, M., Delaygue, G., Delmotte, M., Kotlyakov, V. M., Legrand, M., Lipenkov, V. Y., Lorius, C., Pepin, L., Ritz, C., Saltzmank, E., and Stievenard, M.: Climate and atmospheric history of the past 420,000 years from the Vostok ice core, Antarctica, Nature, 399, 429-436, 1999.

Porter, S. C. and An, Z. S.: Correlation between climate events in the North Atlantic and China during the last glacial maximum, Nature, 375, 305-308, 1995.

Prokopenko, A. A., Williams, D. F., Kuzmin, M. I., Karabanov, E. B., Khursevich, G. K., and Peck, J. A.: Muted climate variations in continental Siberia during the mid-Pleistocene epoch, Nature, 418, 65-68, 2002.

Raymo, M. E., Oppo, D. W., and Curry, W.: The mid-Pleistocene climate transition: A deep sea carbon isotopic perspective, Paleoceanography, 12, 546-559, 1997.

Revel-Rolland, M., De Deckker, P., Delmonte, B., Hesse, P. P., Magee, J. W., Basile-Doelsch, I., Grousset, F., and Bosch, D.: Eastern Australia: A possible source of dust in East Antarctica interglacial ice, Earth Planet. Sci. Lett., 249, 1-13, 2006.

Ridgwell, A. J.: Implications of the glacial $\mathrm{CO}_{2}$ "iron hypothesis" for Quaternary climate change, Geochem. Geophy. Geosy., 4, 1076, doi:10.1029/2003GC000563, 2003.

Rossignol-Strick, M., Paterne, M., Bassinot, F. C., Emeis, K. C., and De Lange, G. J.: An unusual mid-Pleistocene monsoon period over Africa and Asia, Nature, 392, 269-272, 1998.

Rousseau, D.-D., Wu, N. Q., and Guo, Z. T.: The terrestrial molluscs as new indices of the Asian paleomonsoons in the Chinese loess plateau, Global Planet. Change, 26, 199-206, 2000.
Rousseau, D.-D. and Kukla, G.: Abrupt retreat of summer monsoon at the S1/L1 boundary in China, Global Planet. Change, 26, 189198, 2000.

Ruddiman, W. F. and Kutzbach, J. E.: Forcing of late Cenozoic northern hemisphere climate by plateau uplift in southern Asia and the American West, J. Geophys. Res., 94, 18409-18427, 1989.

Ruddiman, W. F.: Orbital insolation, ice volume, and greenhouse gases, Quat. Sci. Rev., 22, 1597-1629, 2003.

Schmittner, A., Saenko, O. A., and Weaver, A. J.: Coupling of the hemispheres in observations and simulations of glacial climate change, Quat. Sci. Rev., 22, 659-671, 2003.

Siegenthaler, U., Stocker, T. F., Monnin, E., Luthi, D., Schwander, J., Stauffer, B., Raynaud, D., Barnola, J. M., Fischer, H., MassonDelmotte, V., and Jouzel, J.: Stable carbon cycle-climate relationship during the late Pleistocene, Science, 310, 1313-1317, 2005.

Singer, M. J., Fine, P., Verosub, K. L., and Chadwick, O. A.: Time dependence of magnetic susceptibility of soil chronosequences on the California coast, Quat. Res., 37, 323-332, 1992.

Vandenberghe, J.: A global perspective of the European chronostratigraphy for the past $650 \mathrm{ka}$, Quat. Sci. Rev., 19, 1701-1707, 2000.

Vidic, N. J., TenPas, J. D., Verosub, K. L., and Singer, M. J.: Separation of pedogenic and lithogenic components of magnetic susceptibility in the Chinese loess/palaeosol sequence as determined by the CBD procedure and a mixing analysis, Geophys. J. Int., 142, 551-562, 2000.

Wang, B.: The Asian Monsoon, Springer, Berlin-Heidelberg-New York, 844 pp., 2006.

Winckler, G., Anderson, R. F., Fleisher, M. Q., McGee, D., and Mahowald, N.: Covariant glacial-interglacial dust fluxes in the equatorial Pacific and Antarctica, Science, 320, 93-96, 2008.

Wu, B. Y. and Wang, J.: Possible impacts of winter Arctic Oscillation on Siberian high, the East Asian winter monsoon and sea-ice extent, Adv. Atmos. Sci., 19, 297-320, 2002.

Yang, S. L. and Ding, Z. L.: Color reflectance of Chinese loess and its implications for climate gradient changes during the last two glacial-interglacial cycles, Geophys. Res. Lett., 30, 2058, doi:10.1029/2003GL018346, 2003.

Yin, Q. Z. and Guo, Z. T.: Mid-Pleistocene vermiculated red soils in southern China as an indication of unusually strengthened East Asian monsoon, Chinese Sci. Bull., 51, 213-220, 2006.

Yin, Q. Z. and Guo, Z. T.: Strong summer monsoon during the cool MIS-13, Clim. Past, 4, 29-34, 2008, http://www.clim-past.net/4/29/2008/.

Zagwijn, W.: The Cromerian complex stage of the Netherlands and correlation with other areas in Europe, in: The early Middle Pleistocene in Europe, edited by: Turner, C., Balkema, Rotterdam, 145-172, 1996. 